\title{
Market research and cost analysis of production of fried shallot as local superior product in Semau Island, East Nusa Tenggara, Indonesia
}

\author{
${ }^{1, *}$ Tulipa, D., ${ }^{2}$ Rachmawati, D., ${ }^{3}$ Ellitan, L. and ${ }^{4}$ Srianta, I. \\ ${ }^{1}$ Faculty of Entrepreneurship, Widya Mandala Catholic University Surabaya, Jalan Dinoyo 42-44 \\ Surabaya, Indonesia \\ ${ }^{2}$ Department of Accounting, Graduate School, Widya Mandala Catholic University Surabaya, Jalan Dinoyo \\ 48 Surabaya, Indonesia \\ ${ }^{3}$ Department of Management, Faculty of Business, Widya Mandala Catholic University Surabaya, Jalan \\ Dinoyo 42-44 Surabaya, Indonesia \\ ${ }^{4}$ Department of Food Technology, Faculty of Agricultural Technology, Widya Mandala Catholic University \\ Surabaya, Jalan Dinoyo 42-44 Surabaya, Indonesia
}

\author{
Article history: \\ Received: 9 July 2019 \\ Received in revised form: 22 \\ August 2019 \\ Accepted: 25 August 2019 \\ Available Online: 30 \\ September 2019
}

\section{Keywords:}

Fried shallot,

Semau island,

Market,

Cost analysis

\section{DOI:}

https://doi.org/10.26656/fr.2017.4(2).250

\begin{abstract}
The purpose of this research was to perform a market research and cost analysis of the fried shallots production. Food product development based on the local agricultural commodities with appropriate technology to the local society in Semau island is an important effort to improve socio-economic development. Shallot is one of the main agricultural commodities in Semau Island. Based on several criteria such as the applied technology, human resources, market potential, and economic contribution, fried shallot has potential as a Local Superior Product from Semau. In this research, fried shallot was developed at laboratory scale and subjected to the chemical analysis, market test and feasibility analysis on the economic aspect. The processing steps of fried shallot include peeling, slicing, mixing, frying and packaging. The results of the chemical analysis showed that moisture and fat contents of the product were comparable to the commercial fried shallot. In the market test, the purchase intention of the product was high enough. Cost analysis showed that the contribution margin ratio was $107 \%$. Based on the technical and economic evaluation, the production of fried shallot was feasible to be implemented on Semau island.
\end{abstract}

\section{Introduction}

The agriculture sector is an important and strategic sector in the Indonesia development structure. Indonesian agriculture has contributed significantly to Indonesia's growth, employment and reduction of poverty. Most of the Indonesian people depend on the agriculture sector (Ellitan, 2017). Hence, the development of the agriculture sector will contribute significantly to the local and regional development. The challenge in the agriculture sector development is to provide long-run sustainability with focus on farmer income. There are an estimated 24 million hectares of dryland areas whose potential is yet to be developed. Semau island (Figure 1) is one of dryland area with rural households whose heavily dependent on agriculture because non-farm rural economies are less robust.

Semau island is located in Kupang District, Province of East Nusa Tenggara. The island is divided into 2 sub-

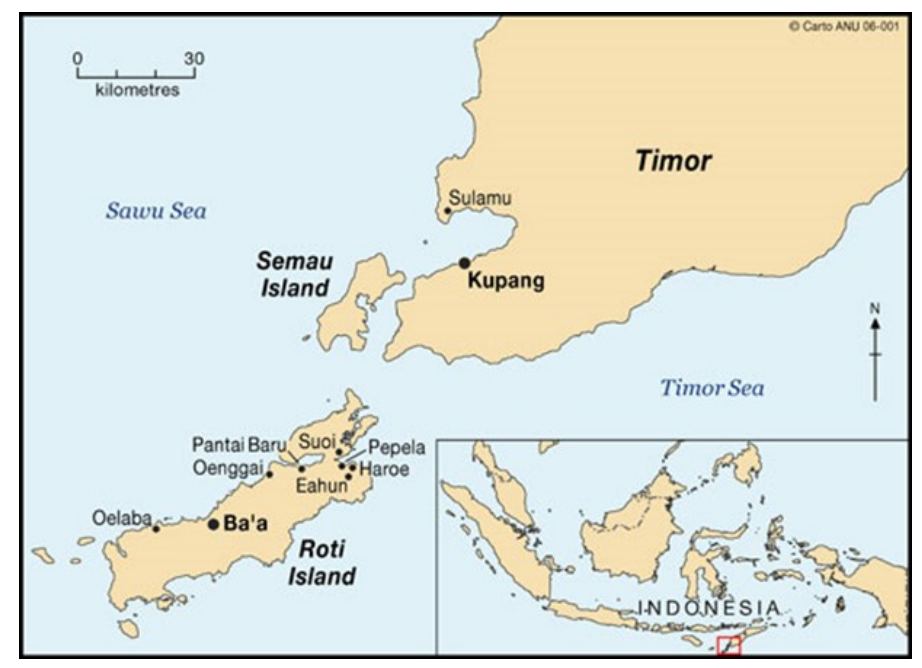

Figure 1. Semau island in Indonesia

districts i.e. Semau sub-district with $143.42 \mathrm{~km}^{2}$ area, 8 villages; and Southern Semau with $153 \mathrm{~km}^{2}$ area, 6 villages. The originated name of Semau island is Nusa Bungtilu which mean island of flower in three colors represented 3 tribes i.e. Helong tribe (represented by 
white), Timor tribe (represented by red) and Rote tribe (represented by black). Semau island has big potency as tourism area since there are 5 beautiful beaches i.e. Liman, Otan, Onanbalu, Uih Make, and Uitiuhtuan. However, the beaches are still quiet, there is not many tourists and lack of facilities. The tourists should prepare the accommodation for their tourism in Kupang.

Based on the situation, the development of higher economic value food product based on local agriculture commodities is a key success factor to contribute to improving the farmer incomes in the areas. Most of Semau island people are farmers with horticulture commodities i.e. shallot, mango, papaya and cashew. Developing Local Superior Product is seen as a way to increase community income. Local Superior Product is made by utilizing local resources and knowledge (material and human), creating value-added activities, and branding local products. Shallot is main agricultural commodity that has potential as a Local Superior Product. They harvest shallot twice a year. The farmers usually sell the harvested commodity directly with unstable price. In order to increase income, it is necessary to add value from raw shallots commodity to fried shallots product.

Shallot (Allium cepa $\mathrm{L}$.) is an onion type widely used to improve the taste and aroma of food products, in which the sulfur compounds as the main contributor. The flavor compounds are produced from their precursors i.e. S-alk(en)yl-L-cysteine sulfoxides which were hydrolized by alliinase into pyruvate, ammonia and volatile and non -volatile sulfur compounds. This reaction occurs when the shallot tissue damage caused by processing such as cutting and cooking. Shallot is also source of phytochemical such as flavonoid, fructooligosaccharide and thiosulphate (Schwimmer and Weston, 1961; Bacon et al., 1999; Prakash et al.,2007; Slimestad et al.,2007; Pérez-Gregorio et al., 2010; Benítez et al., 2011).

Shallot, like other agricultural commodities in general, is a perishable food material. Shallot processing becomes various products can add its economic value and prolong the shelf life. Fried shallot is a shallot product with wide market share, domestic and overseas (Herman, 2007). In general, the processing steps are peeling, washing, cutting, frying and packaging (Anon., 2008). Shallot variety and quality determine the fried shallot characteristic (Herman, 2007). Frying is a critical point in the processing, hence the frying oil quality should be controlled since it determines the product shelf life (Alam et al., 2014).

Fried shallots are a type of food that has been widely known in Indonesia both as a side dish and as a seasoning. Therefore, when introducing products to the market there is no need to introduce the type of product. The important thing to do is to introduce the unique characteristics of fried shallots from Semau. The key of marketing is positioning, differentiation and branding (Kotler and Keller, 2011). Positioning is the way the company determines the target market that involves the identification of the most profitable market segment. A target marketing strategy is focused on customer's need and wants. The company offers a unique product to satisfy the customers that lead the company to use differentiation strategy. Branding is a strategic point of view to create customer value. It is about the management of product image, how to communicate the good of the product to consumers.

There are three basic things that can be done in marketing for this study, those are (1) creating a brand in the form of a product name or symbol that is a product or regional characteristic, (2) use packaging as a product identification, to competing products that have both of visual appeal and are able to protect the contents, (3) communicate the products to consumers by offering products directly to consumers through social media and regional product outlets.

Product readiness and its features need to be assessed for its feasibility to be commercialized. Feasibility studies can be done through calculating production costs that can show if the products bring benefits when it's produced on a small and medium scale industry. Therefore, the objective of this research was to perform market research and cost analysis of the fried shallots production an effort to improve the income of farmers.

\section{Materials and methods}

\subsection{Primary market research}

There are three basic things that can be done in marketing for this study, those are (1) creating a brand in the form of a product name or symbol that is a product or regional characteristic, (2) use packaging as a product identification, to competing products that have both of visual appeal and are able to protect contents, (3) communicate the products to consumers by offering products directly to consumers through social media and regional product outlets.

Packaging is designed to its function as product identification, visual appeal and protection of product contents from outer air contamination so that the product is more durable and not damaged quickly. The packaging for fried shallots was a plastic pouch and jar. Product name and description of the product printed on the sticker and embedded to the plastic pouch or jar. After conducting a packaging study, the next step was to 
conduct market research.

This market research aim was to determine product positioning. Market research was carried out in two stages. The first stage was before the production of fried shallots. The objective was to find out consumer preferences for fried shallots. Respondents are the people who have special knowledge about fried shallot, buys fried shallots for their own consumption and restaurant owner who use fried shallot as a complementary food such as soto, meatballs and fried rice or other foods. Another consideration for selecting respondents is people who often make their own fried shallots. Attributes product of fried shallots includes form, color, texture, aroma, taste and possibility of the selling price is questioned to respondents. The results of the primary research market in the form of product attributes will be used to produce the Semau fried shallots.

\subsection{Materials}

Fresh shallot was obtained from Semau island. Rice flour, salt and frying oil were purchased from the local market. Analytical grade chemicals were purchased from a local distributor.

\subsection{Semau fried shallot processing and chemical analysis}

Semau shallot was peeled, sliced, mixed with salt and rice flour, fried and packed in polypropylene pouch zip lock standing and polyethylene terephthalate jar packaging. The Semau fried shallot was subjected to chemical analysis i.e. proximate composition (moisture, ash, fat and protein contents) by using standard method AOAC and mineral content (Calcium, Potassium, Natrium and Iron) with Atomic Absorption Spectrophotometer (AOAC, 2003).

\subsection{Secondary market research}

The second stage of market research was conducted after the production of Semau fried shallots suitable for commercialization. The survey was conducted to explore respondents' responses after tasting fried shallot. This market research involved broader respondent not only respondent who have special knowledge for fried shallots but also respondent who have the willingness to buy fried shallots or potential consumers.

\subsection{Cost analysis}

The decision-making process requires data that can be measured, properly analyzed and made possible. In decision making there is no general rule that distinguishes costs into relevant or irrelevant costs, therefore to find out which are the relevant costs, a cost analysis is needed which includes the following steps (Mowen et al., 2016): a) Collect all costs related to each alternative considered.

b) Eliminating sunk costs.

c) Eliminating costs that do not differ between alternatives considered.

d) Draw conclusions based on other remaining cost data, which are different costs.

\section{Results and discussion}

\subsection{Primary market research}

First stage market research was conducted to explore consumers' preferences for fried shallot. This study involved respondents who have selected based on their special knowledge about fried shallot. Most of the respondents are female, workers and have monthly income less than IDR 10 million (about USD 690). The preferences about fried shallot characteristic for the texture is thin and crunchy, the form is oval, the color is bright brown, the fragrant is sweet-scented, and the taste is salty. Most respondent inquiry the price for $100 \mathrm{~g}$ fried shallot was IDR 7.500 (USD 0.50/100 g). The order of importance for the fried shallot characteristic was price, taste, color, aroma, form and texture.

\subsection{Fried shallot production}

Figure 2 shows the Semau shallot and fried shallot packed in plastic pouches and jars. The proximate and mineral composition is presented in Table 1. Moisture content is a key parameter of fried shallot quality, which affects the product crispness and shelf life. The moisture content of the fried shallot (3.11\%) was comparable to that of commercial Palu fried shallot reported by Alam et al. (2014) which is in a range of $2.57-4.40 \%$.

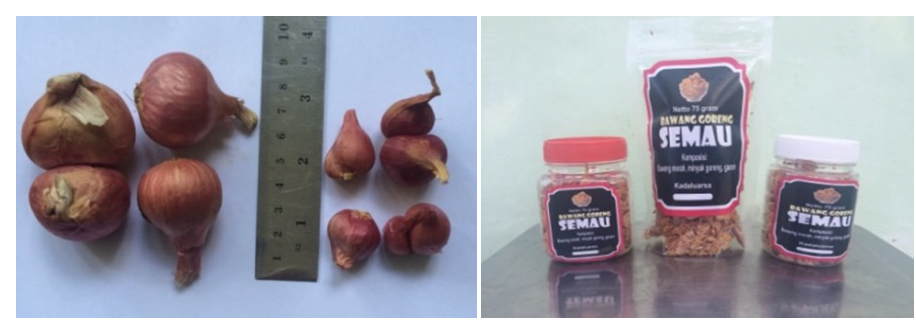

Figure 2. Semau shallot and Semau fried shallot

In general, fat content is an important parameter of fried food. Fat contributes to aroma, taste and appearance of fried food, but it is susceptible to oxidation reaction so it becomes a critical parameter of fried food shelf life. On the nutritional aspect, amount of fat contributes to the calorie content. The Semau fried shallot was slightly oily in appearance, savory taste and aroma. The fat content was lower than that of Palu fried shallot (36.92-42.51\%) as reported by Alam et al. (2014). On nutritional aspect, it can be estimated that consuming $100 \mathrm{~g}$ of Semau fried shallot will give $30.35 \%$ contribution to the fat daily value. 
Table 1. Proximate and mineral composition of Semau fried shallot

\begin{tabular}{lc}
\hline \multicolumn{1}{c}{ Chemical compound } & Content \\
\hline Moisture & $3.11 \%$ \\
Ash & $5.99 \%$ \\
Protein & $3.44 \%$ \\
Fat & $19.73 \%$ \\
Carbohydrate (by difference) & $67.74 \%$ \\
Calsium & $0.5668 \mathrm{mg} / 100 \mathrm{~g}$ \\
Potassium & $0.2763 \mathrm{mg} / 100 \mathrm{~g}$ \\
Sodium & $1.2778 \mathrm{mg} / 100 \mathrm{~g}$ \\
Iron & $0.1096 \mathrm{mg} / 100 \mathrm{~g}$ \\
\hline
\end{tabular}

Ash content reflects the total mineral amount in food. The Semau fried shallot contained $5.99 \%$ of ash due to the mineral content of ingredients used in the formula i.e. shallot, rice flour and salt. Calcium, potassium and sodium are the essential minerals for human body with requirement $>50 \mathrm{mg}$. Sodium overconsumption can lead to blood tension increasing. Though the iron requirement is lower than those minerals, it is essential in hemoglobin, myoglobin and various enzymes such as peroxidase and catalase production (Berdanier et al., 2007; Hounsome et al., 2008; Belitz et al., 2009; Srianta et al., 2012). Consuming $100 \mathrm{~g}$ of Semau fried shallot can contribute to calcium, potassium, sodium and iron body requirement of $0.06 \%, 0.01 \%, 0.05 \%$ and $0.38 \%$, respectively.

Shallot is not a protein source, but the product contains $3.44 \%$ protein. The rice flour may contribute significantly to the protein content. The carbohydrate by the difference of the fried shallot was $67.74 \%$ which could be from the fiber from shallot and starch from the rice flour.

\subsection{Secondary market research}

The secondary market research was conducted after fried shallot is produce. The aim of the second market research was to explore respondents' responses after tasting the fried shallot. Most of the respondents were female, range of age from 35 to 54 years old, workers, have monthly income less than IDR 10 million (USD 690) and as end-user for domestic needs. Respondents usually buy fried shallot package of $100 \mathrm{~g}$ with regular price IDR 10,000 (USD 0.75). The responses for the market analysis of Semau's Fried Shallot are shown in Table 2.

Overall the respondents' assessment of Semau fried shallot was 3.52 that means the respondents agreed to the statements in the questionnaire. The implication of the respondents assessed is the qualifications and specifications of Semau fried shallot was fit with consumers' expectation. The distribution of respondents' perception of Semau fried shallot is shown in Table 3.

\subsection{Cost analysis}

The aim of cost analysis for the Semau fried shallot was to analyze the additional benefits that can be received by shallot farmers when processing fried shallot products. Raw onion as much as $2 \mathrm{~kg}$ will produce $700 \mathrm{~g}$ fried shallots. Based on consumer expectation consumer usually, buy fried shallot package of $100 \mathrm{~g}$ and willing to pay it for IDR 10,000 (USD 0.75). Table 4 shows the cost of production and additional revenue when the farmers produce fried shallots. The additional revenue

Table 2. Attributes of Semau fried shallot

\begin{tabular}{lccccc}
\hline \multicolumn{1}{c}{ Description } & N & Min & Max & Mean & SD \\
\hline Taste & & & & & \\
Savory & 50 & 2 & 5 & 4.1 & 0.678 \\
Salty & 50 & 1 & 5 & 3.9 & 0.931 \\
Fit with respondent taste & 50 & 1 & 5 & 3.84 & 0.912 \\
Price IDR 10,000 / 100 g (about USD 0.75) & & & & \\
Fair & 50 & 2 & 5 & 3.8 & 0.833 \\
More expensive among competitors & 50 & 1 & 5 & 2.82 & 0.941 \\
Color & & & & & \\
Bright Brown & 50 & 2 & 5 & 3.68 & 0.868 \\
Not burning & 50 & 1 & 5 & 2.4 & 1.088 \\
The color is Interesting & 50 & 2 & 5 & 3.54 & 0.838 \\
Texture & & & & & \\
Tin and Crunchy & 50 & 2 & 5 & 3.88 & 0.824 \\
Fit with respondent expectation & 50 & 2 & 5 & 3.8 & 0.904 \\
Aroma & & & & & \\
Sweet-scented & 50 & 2 & 5 & 3.96 & 0.807 \\
Arousing Intention to buy & 50 & 2 & 5 & 3.86 & 0.783 \\
Chopping Shape & & & & & \\
Oval (whole) & 50 & 1 & 5 & 2.8 & 0.99 \\
Irregular form of Chopping & 50 & 1 & 5 & 3.5 & 0.953 \\
Crushed & 50 & 1 & 5 & 2.94 & 1.077 \\
\hline
\end{tabular}


Table 3. The respondents' perception of Semau fried shallot

\begin{tabular}{|c|c|c|c|c|c|}
\hline Description & Strongly Disagree & Disagree & Neutral & Agree & Strongly Agree \\
\hline \multicolumn{6}{|l|}{ Taste } \\
\hline Savory & $0(0 \%)$ & $1(2 \%)$ & $6(12 \%)$ & $30(60 \%)$ & $13(26 \%)$ \\
\hline Salty & $1(2 \%)$ & $3(6 \%)$ & $9(18 \%)$ & $24(28 \%)$ & $13(26 \%)$ \\
\hline Fit with respondent taste & $1(2 \%)$ & $3(6 \%)$ & $10(20 \%)$ & $25(50 \%)$ & $11(22 \%)$ \\
\hline \multicolumn{6}{|c|}{ Price IDR 10,000 / 100 g (about USD 0.75) } \\
\hline Fair & $0(0 \%)$ & $5(10 \%)$ & $8(16 \%)$ & $29(58 \%)$ & $8(16 \%)$ \\
\hline More expensive among competitors & $2(4 \%)$ & $19(38 \%)$ & $17(34 \%)$ & $10(20 \%)$ & $2(4 \%)$ \\
\hline \multicolumn{6}{|l|}{ Color } \\
\hline Bright Brown & $0(0 \%)$ & $7(\%)$ & $8(\%)$ & $19(\%)$ & $6(\%)$ \\
\hline Not burning & $8(16 \%)$ & $26(52 \%)$ & $7(14 \%)$ & $6(12 \%)$ & $3(6 \%)$ \\
\hline The color is Interesting & $0(0 \%)$ & $4(8 \%)$ & $22(44 \%)$ & $17(34 \%)$ & $7(14 \%)$ \\
\hline \multicolumn{6}{|l|}{ Texture } \\
\hline Thin and Crunchy & $0(0 \%)$ & $4(8 \%)$ & $8(16 \%)$ & $28(56 \%)$ & $10(20 \%)$ \\
\hline Fit with respondent expectation & $0(0 \%)$ & $5(10 \%)$ & $11(22 \%)$ & $23(46 \%)$ & $11(22 \%)$ \\
\hline \multicolumn{6}{|l|}{ Aroma } \\
\hline Sweet-scented & $0(0 \%)$ & $3(6 \%)$ & $8(16 \%)$ & $27(54 \%)$ & $12(24 \%)$ \\
\hline Arousing Intention to buy & $0(0 \%)$ & $2(4 \%)$ & $13(26 \%)$ & $25(50 \%)$ & $10(20 \%)$ \\
\hline \multicolumn{6}{|l|}{ Chopping Shape } \\
\hline Oval (whole) & $1(2 \%)$ & $25(50 \%)$ & $9(18 \%)$ & $13(26 \%)$ & $2(4 \%)$ \\
\hline Irregular form of chopping & $1(2 \%)$ & $8(16 \%)$ & $11(22 \%)$ & $25(50 \%)$ & $5(10 \%)$ \\
\hline Crushed & $4(8 \%)$ & $16(32 \%)$ & $11(22 \%)$ & $17(34 \%)$ & $2(4 \%)$ \\
\hline
\end{tabular}

Table 4. Additional revenue for fried shallot production

\begin{tabular}{|c|c|c|c|c|c|c|c|}
\hline \multicolumn{3}{|c|}{ Shallot } & \multicolumn{3}{|c|}{ Fried Shallot } & \multicolumn{2}{|c|}{ Incremental } \\
\hline \multirow[t]{4}{*}{ Shallot $2 \mathrm{~kg}$} & IDR & 40,000 & Shallot $2 \mathrm{~kg}$ & IDR & 40,000 & IDR & 0 \\
\hline & & & Cost of production for $700 \mathrm{~g}$ & & $-27,055$ & & $-27,055$ \\
\hline & & & Sales & & 70,000 & & 70,000 \\
\hline & IDR & 40,000 & & IDR & 82,945 & IDR & 42,945 \\
\hline
\end{tabular}

for farmers when they produced $2 \mathrm{~kg}$ of raw shallot is IDR 42,945 or $107.36 \%$. Therefore, farmers have an alternative to process shallots into fried shallots. The cost of production does not include transportation cost into account, because transportation/shipping cost is paid by consumers.

\section{Conclusion}

The results of the chemical analysis showed that moisture and fat contents of the product were comparable to the commercially produced fried shallot. In the market test, the purchase intention of the product was high enough. Cost analysis on economic aspect showed that the contribution margin ratio was $107 \%$. Based on the technical and economic evaluation, the production of fried shallot was feasible to be implemented on Semau island.

\section{Conflict of Interest}

All authors declare that no conflict of interest

\section{Acknowledgement}

We thank Widya Mandala Catholic University Surabaya for financial support through Interdisciplinary
Research Grant 2018 with contract number of $1001 /$ WM01/N/2018.

\section{References}

Alam, N., Rostiati. and Muhardi. (2014). Sifat fisikkimia dan organoleptik bawang goreng Palu pada berbagai frekuensi pemakaian minyak goreng. Agritech, 34(4), 390-398 [In Bahasa Indonesia]. https://doi.org/10.22146/agritech.9433

Anon. (2008). Bawang goreng komoditi khas Donggala. Gema Industri Kecil, 22, 36-37 [In Bahasa Indonesia].

AOAC, 2003. Official methods of analysis of the association of official's analytical chemists. 17th ed. Arlington, Virginia: AOAC.

Bacon, J.R., Moates, G.K., Ng, A.C. Rhodes, M.J., Smith, A.C. and Waldron, K.W. (1999). Quantitative analysis of flavour precursors and pyruvate levels in different tissues and cultivars of onion (Allium cepa). Food Chemistry, 64(2), 257-261. https:// doi.org/10.1016/S0308-8146(98)00156-3

Belitz, H.D., Grosch, W. and Schieberle, P. (2009). Food Chemistry, $4^{\text {th }}$ revised and extended edition. Berlin Heidelberg, Germany: Springer-Verlag. 
Benítez, V., Mollá, E., Martín-Cabrejasa, M.A., Aguilera, Y., López-Andréu, F.J., Cools, K., Terry, L.A. and Esteban, R.M. (2011). Study of bioactive compound content in different onion sections.Plant Foods for Human Nutrition, 66(1), 48-57. https:// doi.org/10.1007/s11130-011-0212-x

Berdanier, C.D., Dwyer, J. and Feldman, E.B. (2007). Handbook of Nutrition and Food. Boca Raton: CRC Press. https://doi.org/10.1201/9781420008890

Ellitan, L. (2017). Resource Management and Evaluation of Competitive Advantage: a Case Study of East Java Manufacturing Companies. Academic Research International, 8(2), 120-125.

Herman, A.S. (2007). Model agroindustri bawang merah Brebes. Jurnal Riset Industri, 1(1), 45-58 [In Bahasa Indonesia].

Hounsome, N., Hounsome, B., Tomos, D. and EdwardJones, G. (2008). Plant metabolites and nutritional quality of vegetables. Journal of Food Science, 73 (4), R48-R65. https://doi.org/10.1111/j.17503841.2008.00716.x

Kotler, P. and Keller, K.L. (2011). Marketing Management. 14th ed. Boston: Prentice Hall.

Mowen, M.M., Hansen, D.R. and Heitger, D.L. (2016). Cornerstones of Managerial Accounting. $6^{\text {th }}$ ed. Boston: Cengage Learning

Pérez-Gregorio, R.M., García-Falcón, M.S., SimalGándara, J., Rodrigues, A.S. and Almeida, D.P.F. (2010). Identification and quantification of flavonoids in traditional cultivars of red and white onions at harvest. Journal of Food Composition and Analysis, 23(6), 592-598. https://doi.org/10.1016/ j.jfca.2009.08.013

Prakash, D., Singh, B.N. and Upadhyay, G. (2007). Antioxidant and free radical scavenging activities of phenols from onion (Allium cepa). Food Chemistry, 102(4), 1389-1393. https://doi.org/10.1016/ j.foodchem.2006.06.063

Schwimmer, S. and Weston, W.J. (1961). Onion flavor and odor: enzymatic development of pyruvic acid in onion as a measure of pungency. Journal of Agricultural and Food Chemistry, 9(4), 301-304. https://doi.org/10.1021/jf60116a018

Slimestad, R., Fossen, T. and Vågen, I.M. (2007). Onions: a source of unique dietary flavonoids. Journal of Agricultural and Food Chemistry, 55, 10067-10080. https://doi.org/10.1021/jf0712503

Srianta, I., Arisasmita, J.H., Patria, H.D. and Epriliati, I. (2012). Ethnobotany, nutritional composition and DPPH radical scavenging of leafy vegetables of wild Paederia foetida and Erechtites hieracifolia.
International Food Research Journal, 19(1), 245250 . 